Original Article

\title{
"Protect our homeland!" Populist communication in the 2018 Hungarian election campaign on Facebook
}

Tamás Tóth

ORCID: 0000-0002-5361-4300

CORVINUS UNIVERSITY OF BUDAPEST, HUNGARY

Dalma Kékesdi-Boldog

ORCID: 0000-0002-0282-4818

CORVINUS UNIVERSITY OF BUDAPEST, HUNGARY

Tamás Bokor

ORCID: 0000-0001-8221-1212

CORVINUS UNIVERSITY OF BUDAPEST, HUNGARY

Zoltán Veczán

ORCID: 0000-0003-4223-748X

CORVINUS UNIVERSITY OF BUDAPEST, HUNGARY

DOI: 10.19195/1899-5101.12.2(23).4

ABSTRACT: The research presented in this paper is based on analysis of the Facebook posts of five major Hungarian political parties over the course of the official campaign season leading up to the 2018 parliamentary elections. We conducted a mixed-method analysis on 795 Facebook posts. First, the main topics of the parties were collected. Second, the posts of the parties were analyzed from a populist communicational perspective. Third, we tried to find some correlations between the basic topics and the populist communicational categories. Finally, we outline possible differences and similarities between parties' communication. Our analysis shows that opposition parties did not have a common communicational strategy on Facebook while ruling parties emphasized both inner and exterior threats that could destabilize Hungary.

KEYWORDS: populism in Hungary, social media, political communication, campaign rhetoric, populist communication, Hungarian parliamentary campaign in 2018. 


\section{INTRODUCTION}

In recent years, several populist parties gained serious support in the national elections (Schulz, Müller, Schemer, Wirz, Wettstein, \& Wirth, 2017). Shulz and her colleagues emphasized the election results of several European populist parties: "In the national elections of 2014, 2015, and 2016, the citizens of European countries such as Sweden, Finland, Poland, Denmark, and Austria have shown strong support for populist parties and/or their candidates, as indicated by the proportion of voters who sympathized with the Swedish Democrats (12.9\%), the Finns (17.7\%), the Law and Justice Party (51.5\%), the Danish People's Party (21.1\%), or the Freedom Party of Austria (49.7\%)" (Schulz et al., 2017, p. 316).

Perceiving the rising support of populist parties, many authors made the effort to understand and identify the causes for the increasing popularity of populist parties (Albertazzi \& McDonnell, 2008). Several scholars focused on not only populist parties but populist political leaders like Donald Trump in the United States, Geert Wilders in the Netherlands, Marine Le Pen in France and Viktor Orbán in Hungary (Block \& Negrine, 2017; Demeter, 2017; Doerfel \& Taylor, 2017; Engesser, Ernst, Esser, \& Büchel, 2017; Enli \& Rosenberg, 2018; Pal, Chandra, Chirumamilla, Kameswaran, Gonawela, Thawani \& Dasgupta, 2017).

In the last four decades, researchers referred to populism in various ways, for instance as an ideology (Abts \& Rummers, 2007; Canovan, 2002; Kaltwasser, 2012; Mudde, 2007, 2009; Stanley, 2008), a political logic (Laclau 2005a; 2006), a discourse (Laclau, 1977, 1980, 2005b), a political strategy (Weyland, 2001, p. 14), a political style (Moffit \& Tormey, 2014; Mofitt, 2016), a political communication style (Jagers \& Walgrave, 2007), and a communicative act (Hameleers, 2018).

Despite the fact that scholars from different disciplines used a couple of definitions of populism, a remarkable portion of them emphasized that populist rhetoric is based on at least two key factors. First, populist rhetoric appeals to the "people" especially in political campaigns (Ekström \& Morton, 2017). Second, a binary, antagonist comparison emerges between "the ordinary" or "good" people and the "failed," "crooked" or "corrupt" elite (Rooduijn \& Pauwels, 2011). Binary distinction ("good" versus "bad," "ordinary" versus "corrupt") helps to use essential style elements like emotionalization and simplification in populist rhetoric (Bracciale \& Martella, 2017).

In this research we relied primarily on Michael Hameleers' typology of populism in which he stressed the binary oppositions between homogeneous, "good" masses and antagonist groups like the political elite or refugees, the boundaries between "us" and "them": "The core idea of populism as a communicative act can be regarded as the construction of a moral, societal, ideological, or (socio)political divide between the ordinary people as in-group and culprit others as outgroups." (Hameleers, 2018, p. 2173). We chose this definition because the campaign rhetoric of Hungarian parties did not only refer vertically to corrupt and failed (political) 
elites but horizontally to refugees (migrants). On the one hand, vertical oppositions emerge in campaign rhetoric when political actors blame other politicians (businessmen, experts, etc.) for misleading people. On the other hand, horizontal oppositions stress the "threat" that foreign groups (for instance immigrants, asylum seekers) represent to the homeland's citizens (Hameleers, 2018).

Since 2015 one of the most serious problems of the European Union has been the inflow of refugees from war zones and failed states. After the crisis that escalated in Syria in 2015, the European Commission's plan was to divide the refugees between EU countries. The Hungarian prime minister, Viktor Orbán started his forceful opposition against taking in refugees and the EU itself, shifting the Hungarian political agenda from one direction to another: "The most significant difference is the following: many new categories appeared and started to dominate the government's propaganda: among these the most popular were the anti-Brussels narratives" (Demeter, 2018, p. 194). Viktor Orbán blamed the EU's leading politicians, especially Angela Merkel and her Wilkommenskultur and constantly emphasized the danger that refugees represented for Hungary and for the entire EU (Mudde, 2016). On the one hand, anti-Brussels populist rhetoric emerged in the government's and the prime minister's political agenda. On the other hand, an anti-migrant campaign was still overwhelming in 2015 and in 2016 in the government's communication (Bernáth \& Messing, 2015; Demeter, 2018). This rhetoric contained simultaneously vertical and horizontal elements of populist (political) communication: The antagonist, dilettante elite pushed Europe in the wrong direction, which could mean the end of the Christian Europe, while migrants did not want to assimilate to European culture, and finally the continent could not be protected from the expansion of foreign migrant groups. Considering media regulation, media supervision, political communication and the resulting ideological landscape, authoritarian features have risen in Hungarian media policy since 2010 (Bajomi-Lázár \& Kékesdi-Boldog, 2018).

In this empirical case study, we chose those Hungarian parties' Facebook posts which could win seats in the parliament in the 2018 national election. After 2010 Fidesz-KDNP won three elections in a row, therefore it became the most influential party in Hungary. Scholars consider Fidesz-KDNP and its leader, the prime minister, Viktor Orbán as populists because of the anti-elitist (critique against Brussels, George Soros and rival Hungarian parties) and exclusionist (opposition towards migrants) rhetoric they used from 2015 (Bernáth \& Messing, 2015; Demeter, 2018). Nonetheless, "only few articles refer to the post-2010 Fidesz government" (Csigó \& Merkovity, 2016, p. 299). Our reasons to write this paper were threefold. First, as we mentioned above, there is a relatively small number of publications which analyzed the Hungarian campaign rhetoric, especially on Facebook. Second, we wanted to get a detailed picture of Hungarian parties' populist rhetoric to compare it with topics that emerged in the Hungarian political agenda. Third, we tried to draw up the opposition parties' political communication strategy. We wanted to reveal the 
possible similarities and attempt to outline which (populist) rhetoric methods were used in support of or against the ruling coalition. To gain a deeper insight into Hungarian populist campaign rhetoric we compared all parties' Facebook posts during the campaign period.

\section{RESEARCH QUESTIONS}

After collecting the data from the parties' Facebook posts, we focused on two main points: the most common keywords and the populist communication strategies.

RQ1: What were the key topics that emerged in Hungarian political parties' Facebook posts during the campaign? Are these topics connected to (at least) one of the seven utilized populist communication categories?

The first research question is addressed with a quantitative approach. We listed the word combinations from every political parties' posts with MAXQDA12 to get a basic understanding of the most frequently used topics.

We then coded the parties' Facebook posts with trained coders in order to answer the second RQ:

RQ2: What kind of populist communication categories are the most dominant in parties' posts?

Then we tried to find similarities and differences between the parties' populist political communication.

RQ3: Are there similar patterns between the populist political communication categories that were used in the parties' posts? If there are, what are the similarities in populist political communication rhetoric that emerged in the research?

\section{METHOD AND DATA}

The more fashionable populist rhetoric became, the more scholars started to analyze the relevant (populist) texts (public speeches, debates, tweets, etc.) by quantitative and mixed methods in the last decade (Aslanidis, 2018; Bonikowski \& Gidron, 2015; Hawkins \& Kaltwasser, 2018; Pauwels, 2011; Ribera, 2018; Roodujin \& Pauwels, 2011; Schulz et al., 2017). The growing trend of mixed method content analyses encouraged us to analyze the relevant content also by qualitative and quantitative ways. We analyzed five Hungarian political parties' Facebook posts in the last stage of the campaign leading up to the 2018 parliamentary elections in Hungary, which started on February 20, 2018 and ended with election day on April 8, 2018. We focused on parties that reached the minimum necessary amount 
of votes (a minimum of five percent of the valid votes) to enter the Hungarian parliament for the next four-year period. We scanned the following five parties' Facebook posts: Jobbik Magyarországért Mozgalom (Jobbik, the Movement for a Better Hungary), Demokratikus Koalíció (Democratic Coalition), Magyar Szocialista Párt-Párbeszéd Magyarországért alliance (Hungarian Socialist Party-Dialogue for Hungary), Fiatal Demokraták Szövetsége - Kereszténydemokrata Néppárt (Fidesz - Hungarian Civic Alliance-Christian Democratic People’s Party) and Lehet Más a Politika (Politics Can Be Different).

We used the abbreviated terms of the aforementioned parties in the following way: Jobbik, DK, MSZP, Fidesz-KDNP and LMP. Jobbik belongs to the far-right segment of politics; DK and MSZP are connected to the left-wing, Fidesz-KDNP is a conservative right-wing party, while LMP is related to green party politics.

The collected data solely consisted of texts that were posted by the five political parties on Facebook. Furthermore, we analyzed hashtags that emerged in the posts, because these hyperlinks were connected attractively to well-defined topics. We neither analyzed multimedia items such as videos, GIFs, pictures, shared posts, nor comments, likes, shares that were related to any individual user on the social site. In this paper, the term "post(s)" refers strictly to the written posts and hashtags without any multimedia items that were posted on Facebook by the five parties.

We analyzed 795 posts that were published by the five parties. To quantify our textual analysis, we used MAXQDA12 to list the most frequently emerging words and word combinations in the five parties' posts. Word combinations consisted of a minimum of two and maximum of five words. We showed in this research only the word combinations that had at least 0.10 percent share of the relevant party's total word combinations. We created the lists of word combinations by MAXQDA12 and we perceived a couple of key topics in parties' posts (see Table 1). For instance, most of the parties repeated their first nominees' names (Viktor Orbán, Ferenc Gyurcsány, Bernadett Szél, Gergely Karácsony) with very high frequency in the posts to stress the role of the Leader. Obviously, other key topics emerged among the most frequent words and word combinations. Therefore, we created categories like "Leader," "Election Day," "Protecting the homeland," etc. to collect the general key topics that emerged in parties' posts (see "Vertical oppositions" and "Horizontal oppositions" in "Method and Data" chapter). On the other hand, the quantitative analysis provided only essential results that helped, so further analyses were necessary to measure populist rhetoric in Facebook posts. In order to divide the posts into different categories with more precision, further analysis was required. First, we applied seven definitions of populist communication style that emerged in Hameleers' paper (2018). Second, we tried to adapt Hameleers' categories to get more detailed results, based on the listed specific word combinations (Hameleers, 2018). Third, we read every post and categorized it manually. Finally, we calculated intercoder reliability (see Table 1) by the statistical method of Krippendorff's alpha. Krippendorff's alpha's reliability is high between $\alpha \geq 0.800$, results are considerable 
with $0.800>\alpha \geq 0.667$ reliability, however in social sciences the reliability between $0.667>\alpha \geq 0.350$ is still remarkable. We focused only on categories for which intercoder-reliability reached 0.350 as a minimum and which had a minimum frequency of 10 observations (Freelon, 2010). Intercoder reliability was based on the comparison of two trained coders' results to avoid subjective assumptions.

Table 1. Intercoder reliability in populist categories

\begin{tabular}{|l|c|c|c|c|c|}
\hline & $\begin{array}{c}\text { Fidesz- } \\
\text { KDNP }\end{array}$ & Jobbik & MSZP & DK & LMP \\
\hline $\begin{array}{l}\text { Anti-establishment } \\
\text { populism }\end{array}$ & $0.747(67)$ & -0.006 & $\begin{array}{c}0.885 \\
(108)\end{array}$ & -0.036 & $0.719(43)$ \\
\hline $\begin{array}{l}\text { Anti-economic elites } \\
\text { populism }\end{array}$ & $0.907(38)$ & 0.337 & $0.896(27)$ & 0.149 & $0.578(7)$ \\
\hline Anti-experts populism & $1(2)$ & -0.053 & $0.658(3)$ & -0.043 & $0.851(3)$ \\
\hline Anti-media populism & 0 & $0.752(14)$ & $1(5)$ & $0.658(4)$ & $0.648(3)$ \\
\hline $\begin{array}{l}\text { In-group superiority } \\
\text { populism }\end{array}$ & $0.63(89)$ & $0.419(6)$ & -0.093 & -0.007 & undef. \\
\hline Exclusionist populism & $0.646(37)$ & $0.613(8)$ & $0.481(3)$ & $0.741(11)$ & $0.49(1)$ \\
\hline $\begin{array}{l}\text { Welfare state chauvinist } \\
\text { populism }\end{array}$ & $0.67(9)$ & 0.247 & $0.781(26)$ & $0.369(16)$ & $0.708(4)$ \\
\hline
\end{tabular}

Source: Authors.

According to Hameleers, (at least) seven types of populist communication could be observed in political rhetoric (Hameleers, 2018). These categories can be divided into two main groups: vertical opposition and horizontal opposition. Vertical opposition occurs between the ordinary people and elites. The antagonistic relationship exists because the political establishment, the economic elite, the dilettante and ineffective scholars or unreliable media exploit and misguide people. Horizontal opposition, in turn refers to certain out-groups that pose a danger to the homeland's citizens from a cultural, economic and security policy perspective. We categorized the political parties' posts into the following populist communicational categories relying on Hameleers' paper (Hameleers, 2018):

Vertical oppositions:

a) anti-establishment (anti-statist) populism (Jagers \& Walgrave, 2007)

b) anti-economic populism (Elchardus \& Spruyt, 2016; Ramiro, 2017)

c) anti-experts populism (Engesser et al., 2017)

d) anti-media populism (Jagers \& Walgrave, 2007; Pauwels, 2014).

Horizontal oppositions:

a) in-group superiority populism (Tajfel, 1978) 
b) exclusionist populism (Betz, 2004; Fennema, 1997; Oesch, 2008)

c) welfare state chauvinist populism (de Koster, Achterberg, \& Van Der Waal, 2013; Svallfors, 1997).

Moreover, describing the specific adjusted typology of the aforementioned categories is necessary to provide basic information for coders. If the analyzed posts had contained at least one of the elements of the following descriptions the coders assigned it to the respective category.

Anti-establishment (anti-statist) populism primarily refers to the ruling parties (in this case to members of Fidesz-KDNP) from the opposition parties' perspectives. In the following lines we refer to the aforementioned category as antiestablishment populism. However, we completed this category with messages that attacked opposition parties or politicians, because the ruling party systematically emphasized the home affairs rivals' mistakes and defects. Therefore, in our research, not only were the ruling parties the focus point of the anti-establishment populism, so too were the opposition parties and their candidates connected to our typology. Party messaging that stressed other parties' or politicians' insufficiencies were categorized as anti-establishment populism. Moreover, one of the primary topics in the Fidesz-KDNP campaign communication was George Soros, who represented the antagonist (individual) character in the ruling parties' rhetoric. FideszKDNP alleged during the campaign period that Soros constructed the so-called Plan Soros that could be a risk at the economic and (defense) political level. Hence, we categorized posts where Soros was mentioned both into the anti-establishment (anti-statist) and anti-economic categories. In the remainder of the paper we refer to the aforementioned category as anti-establishment populism.

Certain companies or businessmen that allegedly had connections to one of the political parties or politicians were mentioned regularly in Facebook posts during the campaign season by the five parties. Mostly these references appeared in a negative context. For instance, István Tiborcz, the prime minister's son-in-law had interests in a company called Elios Ltd. which allegedly could have been part of a financial scandal, based on OLAF reports. These kinds of posts were categorized as anti-economic populism posts.

For instance, referring to the attorney general, public opinion researcher companies and the Klebelsberg Center (the department that maintains basic resources and supervises criteria at education institutes), was part of the anti-expert populism category if the post refers to any scandal or omission that can harm citizens by experts.

Anti-media populism refers to national public service media emerging in posts as a messenger of the ruling parties. This allegation came from opposition parties. By contrast, Fidesz-KDNP's posts did not mention the possible connection between the media and opposition parties.

In-group superiority populism is pushed forcefully in Facebook campaign posts to emphasize that protecting the homeland is one of the most important issues of 
the country. Protecting the cultural values and maintaining the security of the Hungarian people was a key perspective during the campaign for a couple of parties. This communication had its roots in the "anti-migrant" or "anti-refugee" topics. On the one hand, Fidesz-KDNP utilized those concepts, on the other, Jobbik temporarily focused on the protection of the motherland too. If "protecting" or "defending" efforts or issues appeared in the relevant post(s), then they were part of the in-group superiority rhetoric.

Exclusionist populist communication did not only refer to the "anti-migrant" or "anti-refugee" topics but to another certain group. DK's case can provide an illustration for this category: it emphasized that Hungarian people who were born beyond the borders should not have been allowed to participate in the Hungarian parliamentary elections. DK's fundamental allegation beyond the exclusionist communication was that Hungarian minorities (primarily in Transylvania) would have supported Fidesz-KDNP by their votes.

In this research welfare state chauvinist populism was expanded to any entity or group who exploited financially ordinary citizens. Exploiting means in this concept, that the mentioned entities or groups took money away, mainly indirectly, from the homeland's honest people via the social security system, disputable businesses, (stock market) speculations, etc.

\section{FINDINGS}

The most active party on Facebook during the campaign phase was DK $(n=208)$, followed by Fidesz-KDNP $(n=187)$, Jobbik $(n=170)$, MSZP $(n=154)$ and LMP $(n=76)$ (see Figure 1).

As the quantitative analysis showed, Jobbik had the highest unique word amount $(n=5,303)$ and highest number of word frequency $(n=11,421)$ in the analyzed posts as well. It was followed by DK $(n=3,058, n=6,683), \operatorname{MSZP}(n=2,468, n=5,028)$, Fidesz-KDNP $(n=2,044, n=4,623)$ and LMP $(n=2,001, n=3,386)$. Jobbik had the highest total of words among word combination lists with its 1,851 frequency. It was followed by Fidesz-KDNP $(n=1,025)$, DK $(n=879), \operatorname{MSZP}(n=810)$ and LMP $(n=410)$.

We listed the most frequently used word combinations (see Table 2) by parties. The abbreviated terms of "sh" meant to be the total share of the word combinations in the relevant sample. The word combination "on April 8th" had significant frequency in every parties' posts. Jobbik $(n=75)$, DK $(n=72)$ and Fidesz-KDNP $(n=54)$ also emphasized the importance of the election date with the highest frequency in their posts.

MSZP was the party that mostly leant on its first candidate's charisma (name $n=$ 158). LMP was another party that put a lot of emphasis on the name of its first candidate (Bernadett Szél, $n=35$ ). Neither Jobbik, nor Fidesz-KDNP mentioned any kind of allies or inner members of their parties' within the minimum share of $0.10 \%$. 


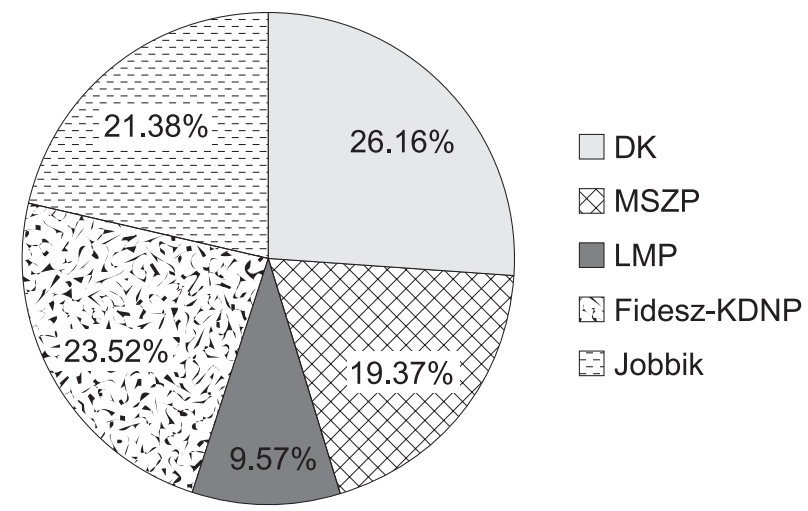

Figure 1. The share of posts in Hungarian parties' Facebook campaign

Source: Authors.

Former prime minister (from 2004 to 2009), and leading candidate of DK Ferenc Gyurcsány $(n=52)$ and the current prime minister Viktor Orbán were also frequently mentioned in DK's posts. In Jobbik's posts the name of the lead candidate ("Gábor Vona") appeared 26 times. Nonetheless, this frequency was not enough to reach the minimum share of $0.10 \%$.

The quantitative analysis showed that certain parties emphasized the name of other party members or political allies in their posts. MSZP, DK and LMP were among the parties which referred to their allies. In MSZP's posts the coalition of "MSZP-Párbeszéd", the common list "No 9. MSZP-Párbeszéd" and "MSZPPárbeszéd alliance" were stressed with high frequency $(n=89)$. The summarized frequency of the above word combinations had the total share of $0.66 \%$ of the relevant corpus respectively. By contrast, the party of DK referred to individual entities who were members of the Democratic Coalition $(n=37, s h=0.23 \%)$. However, DK also brought attention to the list by using "No. 3" and "to list No. 3" word combinations $(n=117)$. The first word combination had a frequency of 72 and share of $0.46 \%$, while the second emerged 45 times with $0.29 \%$ share of the analyzed sample. References to the party (DK) occurred with the frequency of 31 and share of $0.20 \%$.

We also observed antagonist attitudes in parties' rhetoric. The category of Enemy emerged significantly in all the parties' posts except MSZP. Jobbik and LMP used the name of the prime minister ("Viktor Orbán," $n=27, n=11$ ) directly, while in DK posts the word combination "no deal" referred to the lack of cooperation with Viktor Orbán 13 times out of 15 occasions.

We used the content analysis results from Figure 2 to show the connections between parties and populist categories (see Table 1). We showed only correlation combinations of parties and populist communication categories if Krippendorff's alpha reached the minimum margin of 0.350 for the respective category. 
Tamás Tóth, Dalma Kékesdi-Boldog, Tamás Bokor, and Zoltán Veczán

Table 2. Top word combinations in the analyzed parties' posts

\begin{tabular}{|c|c|c|c|c|}
\hline Jobbik & DK & MSZP & Fidesz-KDNP & LMP \\
\hline on April 8th & No.3 & $\begin{array}{c}\text { Gergely } \\
\text { Karácsony }\end{array}$ & on April 8th & Bernadett Szél \\
\hline we succeed & on April 8th & change now & forward it & the LMP \\
\hline among others & $\begin{array}{c}\text { Ferenc } \\
\text { Gyurcsány }\end{array}$ & on April 8th & pass on & can be different \\
\hline further details & $\begin{array}{c}\text { vote on April } \\
\text { 8th }\end{array}$ & $\begin{array}{c}\text { the MSZP-Pár- } \\
\text { beszéd }\end{array}$ & must & on April 8th \\
\hline you win & $\begin{array}{c}\text { list No.9 } \\
\text { MSZP-Pár- } \\
\text { beszéd }\end{array}$ & Viktor Orbán & Viktor Orbán \\
\hline Viktor Orbán & $\begin{array}{c}\text { Democratic } \\
\text { Coalition }\end{array}$ & live consultation & this Sunday & Ákos Hadházy \\
\hline
\end{tabular}

Source: Authors.

MSZP and anti-establishment populism

Fidesz-KDNP and in-group superiority...

Fidesz-KDNP and anti-establishment populism

LMP and anti-establishment populism

Fidesz-KDNP and anti-economic populism

Fidesz-KDNP and exclusionist populism

MSZP and anti-economic elites populism MSZP and welfare state chauvinist populism

DK and welfare state chauvinist populism Jobbik and anti-media populism

DK and exclusionist populism

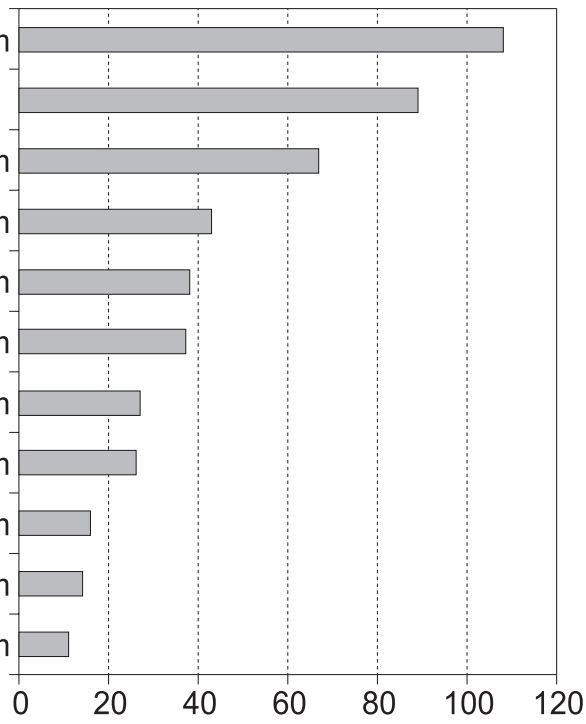

Figure 2. Frequency of certain categories of populism on the Facebook accounts of parties

Source: Authors.

Anti-economic elites populism had the highest intercoder reliability in Fidesz' posts, however anti-establishment populism and welfare state chauvinist populism also showed significant reliability. Furthermore, in-group superiority populism was the most frequently used category $(n=89)$, followed by anti-establishment populism $(n=67)$, anti-economic populism $(n=38)$ and exclusionist populism $(n=$ 37). On the other hand, no written texts referred to anti-media populism in Fidesz' Facebook posts. 
The highest reliability in Jobbik's posts was observed for the anti-media populism category $(n=17)$, while exclusionist populism and in-group superiority populism still had considerable reliability.

In MSZP's posts the most frequently emerging form of populism was anti-establishment populism $(n=108)$ which was measured with a very high reliability.

In DK's posts, exclusionist populism provided the most significant reliability in intercoder agreement and occurred eleven times. Anti-media populism and welfare state chauvinist populism were considerably part of DK's Facebook campaign and occurred four and sixteen times, respectively. Nonetheless, it is important to note that DK's antimedia populist rhetoric had a very low and probably negligible frequency $(n=4)$.

LMP's campaign posts showed that anti-establishment populism had the highest frequency $(n=43)$ and was measured with a high reliability.

\section{DISCUSSION}

\section{Key topics in party posts}

The first research question (RQ1) referred to key topics that emerged in the analyzed political parties' listed word combinations.

We could observe the key importance of the election date in Hungarian parties' Facebook rhetoric. All the parties focused on the election date heavily to make voters remember to participate in the elections. Therefore, we can say that "Election Day" is one of the most commonly used categories in the analyzed sample. All parties made serious efforts to make citizens remember the date "on April 8th" in order to mobilize their supporters.

Raising awareness of the parties' own leaders was another frequent topic. In Fidesz-KDNP's narrative Viktor Orbán was the leader who could help protect the homeland's and the EU's security from the inflow of migrants. With the exception of Jobbik, every opposition party emphasized the role of their first nominee, who could change the current "regime." Gábor Vona, the former president of Jobbik, could not emerge among the most frequent word combinations. We can state that the category of "Leader" was still a prominent theme in parties' posts, however Jobbik did focus on its own leader.

Activating people on Facebook was a common strategy in the posts of three parties. Fidesz-KDNP and MSZP stressed the importance of content sharing. More precisely, MSZP mixed its strategy up by sharing and consuming the content ("share it," "watch it," etc.) while Fidesz-KDNP focused primarily on making people share and forward their posts. In addition, the ruling party stressed that every vote was important in the election, therefore everybody was needed to beat the opposition. DK did not focus on content sharing, but it encouraged people to go out and vote for the Democratic Coalition. Jobbik and LMP did not pay much attention to activating people. 
Protecting the homeland and inhabitants was one of the main parts of Fidesz-KDNP's posts. Protecting and defending appeared as a collective project, because the ruling parties mainly used "we" instead of "our party," "the party," "the government," etc. in this issue. The word "we" refers not only to party members but also to the people. The term "we" emerged in another international analysis as a key term of populist rhetoric (Rooduijn \& Pauwels, 2011).

Interestingly, we observed that the Democratic Coalition focused on Hungarian people who were born and lived beyond Hungary's border in its posts. DK underlined that they would terminate the right of Hungarians beyond its borders to participate in Hungary's parliamentary election. Excluding the aforementioned group of people was one of the standard topics in DK's Facebook posts.

Based on our quantitative approach, certain groups of the listed word combinations correlated to three utilized populist communication categories. Firstly, "Enemy" matches anti-establishment populism and anti-economic populism, secondly "Protecting the homeland" is related to in-group superiority populism and finally "Excluding" corresponded to exclusionist populism.

\section{Populist communication in Hungarian parties' posts}

The second research question (RQ2) referred to the possible utilization of seven populist communication categories in five Hungarian parties' Facebook posts (see Table 1).

\section{Anti-establishment populism}

Fidesz-KDNP criticized Hungarian politicians, the United Nations and EU (Brussels) because of their migration politics. The government stressed that the oppositional politicians are too weak to protect the country from a migration crisis. In addition, Fidesz-KDNP alleged that the opposition "is in Soros' pocket" and they do not want to stop the so-called Plan Soros. Fidesz' allegation was that George Soros wanted to destabilize Hungary using incoming refugees. The UN and EU created a "migration package" in Fidesz-KDNP's rhetoric that also "must be stopped." Furthermore, a part of Fidesz-KDNP's anti-establishment posts was based on the allegation that the UN and EU wanted to make Hungary give up its anti-migrant politics.

By contrast, MSZP focused on much more diverse topics than Fidesz-KDNP did in the posts that were connected to anti-establishment populism. For instance, MSZP emphasized that the prime minister "should not have used innocent faces and children" in his campaign. This case emerged when Viktor Orbán appeared in a video where he was photographed with a group of children in a kindergarten. Moreover, the left-wing party stressed that Viktor Orbán re-spent billions on sports and stadiums without any results. MSZP also alleged that members of FideszKDNP abused their position when they spent financial support coming from the EU. MSZP used the hashtag "Change NOW!" with a frequency of 67 that relied on changing the political establishment. 
LMP did not focus on primarily the prime minister in its anti-establishment rhetoric, it stressed rather the government's abuses and incompetence $(n=45)$. For instance, LMP underlined that Fidesz (in the posts Fidesz' coalition partner, KDNP was mentioned only twice) exploited the national media and used it as a propaganda machine. LMP emphasized that the government acted like a totalitarian party, because hate speech and listing oppositional citizens are part of the ruling parties' tactics. On the one hand, LMP alleged that the government was afraid of accountability, on the other hand, Fidesz-KDNP used fear to control people.

\section{Anti-economic populism}

On the one hand, Fidesz-KDNP emphasized the destructive role of George Soros in politics and the economy, on the other hand, the government found another person to draw attention to in anti-economic populism. Csaba Czeglédy, who was in pre-trial detention because of his possible participation in tax fraud, became a regular target in ruling parties' Facebook posts, because he wanted be an independent nominee and participate in the parliamentary elections. Fidesz-KDNP alleged a possible connection between Czeglédy and the left-wing parties. Fidesz-KDNP posted that "Czeglédy's crime organization cheated billions and he could be one the cashiers of MSZP and DK."

MSZP primarily focused on the Elios scandal in its anti-economic populism rhetoric. The OLAF report 2017 was an investigation that scanned lighting projects in Hungary A part of the report showed possible mishandling of EU funds observed in Hungary. MSZP alleged that this corruption case was connected to István Tiborcz, the prime minister's son-in-law. MSZP stressed that other EU funds were stolen by Fidesz and its members. Among others, the left-wing alliance posted about possible frauds that were connected to Antal Rogán, who is a member of Fidesz and a minister of the Prime Minister's Cabinet Office. For instance, "Rogán’s business partner took an EU fund worth 256 million for fake inventions [...]."

\section{Anti-experts populism}

We could not find a significant number of anti-experts populism in the analyzed posts.

\section{Anti-media populism}

"In 2009, Jobbik was predominantly a young people's party with nationalist and antiRoma sentiments, not an economic party” (Karácsony \& Róna, 2010). According to these scholars, the party's success should rather be explained by "the concentration on Roma-related conflicts." (Csigó \& Merkovity, 2016, p. 307). Despite the fact that we referred to Jobbik as a radical right-wing party, in recent years the president and candidate of Jobbik, Gábor Vona tried to make efforts to re-position the party from radical to conservative. As a result, no discriminative posts were published by Jobbik in the campaign phase, but another type of populist rhetoric was observed by us 
in our research. According to frequency analysis, Jobbik was the only party which used anti-media populism with significant frequency $(n=14)$ and this was measured with high reliability (0.752). Jobbik stressed that Fidesz-KDNP "took control over the national media" and the ruling parties' propaganda reached people via print publications like Magyar Idők (Hungarian Times) and posters that were in nation-wide circulation. Nevertheless, Jobbik emphasized that social media provides a chance to update people about the "truth and oppositional opinion."

\section{In-group superiority and exclusionist populism}

None of the parties posts had high intercoder reliability at in-group superiority but Fidesz-KDNP posts still had a remarkable reliability in coder's agreements $(r=0.63$, $n=89$ ). Despite the fact that this result was marginal, we observed that one of key topics and issues of the ruling parties was the protection of the homeland. Defending Hungary from migrants and "keep Hungary as a Hungarian state" were part of the ideology that backed Fidesz-KDNP's rhetoric not only in Facebook posts but in electronic, tabloid media and on giant posters too. Exclusionist populism and in-group populism often emerged together in Fidesz-KDNP's posts. Declining "the EU latest migration proposal" and the allegation that "Europe does not need the current migration" point to other problematic opponent(s) besides migrants, the EU. Moreover, different variations of the word "immigration" emerged 84 times in the analyzed posts. The word combinations of "immigration country," "immigrant city," "supporter(s) of immigration," etc. were a standard part of the Fidesz-KDNP Facebook rhetoric. Avoiding "transforming into an immigrant country" was the basic concept that needed to use in-group superiority populism and exclusionist populism.

As we mentioned in key topics in party posts, DK was a party that used exclusionist populism when referring to Hungarian people who were born beyond Hungary's borders. The current president of DK, the former prime minister (who was member of MSZP between 2000 and 2011) Ferenc Gyurcsány opposed "aye" that would have provided dual citizenship for Hungarian people who were born beyond Hungary's borders in November 2004. However, although Gyurcsány changed parties, his basic politics did not change in this matter, because he thought that dual citizens "will not endure the consequences of their decisions."

\section{Welfare state chauvinist populism}

Intercoder reliability was considerable only in MSZP's posts because the coders found 25 posts that referred to the welfare state chauvinist category. In contrast, the other parties did not focus primarily on the welfare state chauvinist aspect (see Table 1). MSZP's key political rhetoric referred strongly to general social problems like poor salaries in public healthcare and corruption in the political sphere. MSZP emphasized that they want "Fair pensions and social allocations from the stolen billions." MSZP blamed the ruling party for the financial deficit which caused serious damage, mostly in healthcare. The left-wing party stressed that they would take back the money stolen 
by the ruling parties from ordinary Hungarian people. MSZP promised that they would invest in healthcare from the stolen amount. MSZP emphasized that EU funds stolen by Fidesz-KDNP would have been enough to "get back on the country's feet."

\section{Possible similarities in populist posts between Hungarian parties}

The third research question (RQ3) referred to possible similar patterns in the parties' populist communication.

Neither left-wing parties (MSZP and DK), nor the green party (LMP) focused on in-group superiority, because they did not post about foreign or alien groups or entities that could "threaten" Hungary.

Anti-economic populism was present both in Fidesz-KDNP and MSZP's posts, but their perspectives were different. The government stressed a certain individual's role in possible economic frauds (Soros, Czeglédy), while MSZP mentioned the possible connection between the prime minister's son-in law, and a company (Elios Ltd.) that could have been connected to the EU funds scandal, based on the OLAF report.

None of the parties focused seriously on anti-expert populism in their posts.

\section{Limitations}

This research has considerable limitations. We did not analyze videos, GIFs, pictures, shared posts, or comments, likes, shares in this paper. To get a more detailed picture of political party communication on Facebook in Hungary, the above content needed to be analyzed, which would also require an expansion of the sample size. With this in mind, there is a possibility that more links can be observed between the posts and populist categories. The typologies of categorizing should be reconsidered to gain a deeper insight into parties' communicational strategies.

\section{CONCLUSION}

Despite the fact that every opposition party stressed the need for political change, they did not have a common (populist) communication strategy against the government in their written Facebook posts. For instance, in MSZP's posts "\#ChangingNow!" was a standard short term (hashtag) that referred to anti-establishment populism, while Jobbik repeated its slogan "We succeed, you win," and DK used the "No deal with Orbán" sentence regularly. All the three types of messages were connected to anti-establishment populism, but in different ways: MSZP's hashtag was too general, Jobbik's slogan sentence required too long an explanation (for instance, what people will win?), DK's declining attitude brought attention to the paradox idea of a possible deal with Orbán. The parties focused on mostly two antagonist individuals in their posts, the government emphasized George Soros' role in the migrant crisis, while the opposition brought attention to prime minister Viktor Orbán. 
Jobbik used to have a far-right political political perspective, focusing on primarily ethnical questions by utilizing a radical and exclusionist tone. During the campaign, Jobbik changed its strategy by shifting its focus from ethnical populist topics to another one, namely anti-media populism. In this case, modifying the tone in Jobbik's populist rhetoric means that Jobbik tried to communicate like a conservative party rather like a far-right one. Despite the fact that Jobbik published the longest posts, it could not stress the populist binary difference between people and government. Therefore, the difference between the antagonist party (and leader) and biggest opposition party (Jobbik) was not attractive. Most of the parties emphasized the presence and importance of their first nominees (especially MSZP), but Jobbik did bring attention to the role of Gábor Vona in its Facebook posts.

In-group superiority populism and exclusionist populism were considerable parts of the Fidesz-KDNP posts. Protecting and defending Hungary, the fear of "transforming into an immigrant country" and the emphasis of "weak politicians who wanted to make immigrants move to Hungary" were fundamental topics in the winning party's posts. Fidesz-KDNP developed a special campaign rhetoric via Facebook, in which the foreign policy crisis was used to reach their internal affairs goals. We can conclude that the difference in in-group superiority populism and exclusionist populism were very small, practically imperceptible in Fidesz-KDNP written messages on Facebook as they emerged together in the ruling parties' posts.

\section{REFERENCES}

Abts, K., \& Rummens, S. (2007). Populism versus democracy. Political Studies, 55(2), 405-424.

Albertazzi, D., \& McDonnell, D. (Eds.). (2008). Twenty-first century populism: The spectre of Western European democracy. Basingstoke, UK: Palgrave.

Aslanidis, P. (2018). Measuring populist discourse with semantic text analysis: An application on grassroots populist mobilization. Quality \& Quantity, 52(3), 1241-1263.

Bajomi-Lázár, P., \& Kékesdi-Boldog, D. (2018). Zurück in die Zukunft. Autoritäre Medienpolitik in Ungarn. Osteuropa, 3-5, 273-282.

Bernáth, G., \& Messing, V. (2015). Bedarálva: A menekültekkel kapcsolatos kormányzati kampány és a töle független megszólalás terepei [Governmental anti-migrant narratives and the potentials of independent discourses]. Médiakutató, 16(4), 7-17.

Betz, H. G. (2004). Exclusionary populism in Western Europe in the 1990s and beyond, program paper no. 9. New York: United Nations Research Institute for Social Development.

Block, E., \& Negrine, R. (2017). The populist communication style: Toward a critical framework. International Journal of Communication, 11, 178-197.

Bonikowski, B., \& Gidron, N. (2015). The populist style in American politics: Presidential campaign discourse, 1952-1996. Social Forces, 94(4), 1593-1621.

Bracciale, R., \& Martella, A. (2017). Define the populist political communication style: The case of Italian political leaders on Twitter. Information, Communication \& Society, 20(9), 1310-1329.

Canovan, M. (2002). Taking politics to the people: Populism as the ideology of democracy. In Y. Mény \& Y. Surel (Eds.), Democracies and the populist challenge (pp. 25-44). Basingstoke: Palgrave Macmillan. 
Csigó, P., \& Merkovity, N. (2016). Hungary: Home of empty populism. In T. Aalberg, F. Esser, C. Reinemann, J. Stromback \& C. de Vreese (Eds.), Populist political communication in Europe (pp. 299325). New York: Routledge.

de Koster, W., Achterberg, P., \& Van Der Waal, J. (2013). The new right and the welfare state: The electoral relevance of welfare chauvinism and welfare populism in the Netherlands. International Political Science Review, 34(1), 3-20.

Demeter, M. (2017). Control, communication, and the voice of the leader: A control-character analysis of the 2016 us presidential debate. KOME - An International Journal of Pure Communication Inquiry, 5(1), 40-64.

Demeter, M. (2018). Propaganda against the West in the Heart of Europe: A masked official state campaign in Hungary. Central European Journal of Communication, 11, 177-197.

Doerfel, M. L., \& Taylor, M. (2017). The story of collective action: The emergence of ideological leaders, collective action network leaders, and cross-sector network partners in civil society. Journal of Communication, 67(6), 920-943.

Ekström, M., \& Morton, A. (2017). The performances of right-wing populism: Populist discourse, embodied styles and forms of news reporting. In M. Ekström \& A. Morton (Eds.), The mediated politics of Europe: A comparative study of discourse (pp. 289-316). Cambridge: Palgrave Macmillan.

Elchardus, M., \& Spruyt, B. (2016). Populism, persistent republicanism and declinism: An empirical analysis of populism as a thin ideology. Government and Opposition, 51(1), 111-133.

Engesser, S., Ernst, N., Esser, F., \& Büchel, F. (2017). Populism and social media: How politicians spread a fragmented ideology. Information, Communication \& Society, 20(8), 1109-1126.

Enli, G., \& Rosenberg, L. T. (2018). Trust in the age of social media: Populist politicians seem more authentic. Social Media and Society, 4(1), 1-11.

Fennema, M. (1997). Some conceptual issues and problems in the comparison of anti-immigrant parties in western Europe. Party Politics, 3(4), 473-492.

Freelon, D. (2010). ReCal: Intercoder reliability calculation as a web service. International Journal of Internet Science, 5(1), 20-33.

Hameleers, M. (2018). A typology of populism: Toward a revised theoretical framework on the sender side and receiver side of communication. International Journal of Communication, 12, 2171-2190.

Hawkins, K. A., \& Kaltwasser, C. R. (2018). Measuring populist discourse in the United States and beyond. Nature Human Behaviour, 2(4), 241-242.

Jagers, J., \& Walgrave, S. (2007). Populism as political communication style: An empirical study of political parties discourse in Belgium. European Journal of Political Research, 46(3), 319-345.

Kaltwasser, C. R. (2012). The ambivalence of populism: Threat and corrective for democracy. Democratization, 19(2), 184-208.

Karácsony, G. \& Róna, D. (2010). A Jobbik titka: a szélsőjobb magyarországi megerősödésének lehetséges okairól [The Jobbik Secret. Possible reasons for the strengthening of the far-right in Hungary]. Politikatudományi Szemle, 19(1), 31-63.

Laclau, E. (1977). Politics and ideology in Marxist theory. London: New Left Books.

Laclau, E. (1980). Populist rupture and discourse. Screen Education, 34(Spring), 87-93.

Laclau, E. (2005a). On populist reason. London: Verso.

Laclau, E. (2005b). Populism: What's in a name? In F. Panizza (Ed.), Populism and the mirror of democracy (pp. 32-49). London: Verso.

Laclau, E. (2006). Why constructing a people is the maintask of radical politics. Critical Inquiry, 32(4), 646-680.

Moffitt, B. (2016). The global rise of populism: Performance, political style, and representation. Stanford: Stanford University Press.

Moffitt, B., \& Tormey, S. (2014). Rethinking populism: Politics, mediatisation and political style. Political Studies, 62(2), 381-397.

Mudde, C. (2007). Populist radical right parties in Europe. Cambridge: Cambridge University Press. 
Mudde, C. (2009). Populist radical right parties in Europe Redux. Political Studies Review, 7(3), $330-337$.

Mudde, C. (2016). Europe's populist surge: A long time in the making. Foreign Affairs, 95, 25-30.

Oesch, D. (2008). Explaining workers' support for right-wing populist parties in Western Europe: Evidence from Austria, Belgium, France, Norway, and Switzerland. International Political Science Review, 29, 349-373.

Pal, J., Chandra, P., Chirumamilla, P., Kameswaran, V., Gonawela, G., Thawani, U., \& Dasgupta, P. (2017). Innuendo as outreach: @narendramodi and the use of political irony on Twitter. International Journal of Communication, 11, 4197-4218.

Pauwels, T. (2011). Measuring populism: A quantitative text analysis of party literature in Belgium. Journal of Elections, Public Opinion and Parties, 21(1), 97-119.

Pauwels, T. (2014). Populism in Western Europe: Comparing Belgium, Germany and the Netherlands. London, UK: Routledge.

Ramiro, L. (2017). Radical-left populism during the Great Recession: Podemos and its competition with the established radical left. Political Studies, 65(15), 108-126.

Ribera, P. P. (2018). Measuring populism in Spain: Content and discourse analysis of Spanish political parties. Journal of Contemporary European Studies, online first, 1-33. Retrieved October 22, 2018, from https://www.tandfonline.com/doi/pdf/10.1080/14782804.2018.1536603?casa_token=e614LRUwNjQAAAAA:7lE9u25E6FaJqWwAxxb4HRj17r3PjSp9m2NQm4XlJsenuwoKAI8K C0Hzlxo8vozjjsvRrTSC2L3a.

Rooduijn, M., \& Pauwels, T. (2011). Measuring populism: Comparing two methods of content analysis. West European Politics, 34(6), 1272-1283.

Schulz, A., Müller, P., Schemer, C., Wirz, D. S., Wettstein, M., \& Wirth, W. (2017). Measuring populist attitudes on three dimensions. International Journal of Public Opinion Research, 30(2), 316-326.

Stanley, B. (2008). The thin ideology of populism. Journal of Political Ideologies, 13(1), 95-110.

Svallfors, S. (1997). Worlds of welfare and attitudes to redistribution: A comparison of eight Western countries. European Sociological Review, 13(2), 283-304.

Tajfel, H. (1978). Social categorization, social identity, and social comparisons. In H. Tajfel (Ed.), Differentiation between social groups (pp. 61-76). London, UK: Academic Press.

Weyland, K. (2001). Clarifying a contested concept: Populism in the study of Latin American politics. Comparative Politics, 34(1), 1-22. 